\title{
The three faces of bounded reliability: Alfred Chandler and the micro-foundations of management theory
}

Article

Accepted Version

Kano, L. and Verbeke, A. (2015) The three faces of bounded reliability: Alfred Chandler and the micro-foundations of management theory. California Management Review, 58 (1). pp. 97-122. ISSN 2162-8564 doi:

https://doi.org/10.1525/cmr.2015.58.1.97 Available at https://centaur.reading.ac.uk/59132/

It is advisable to refer to the publisher's version if you intend to cite from the work. See Guidance on citing.

To link to this article DOI: http://dx.doi.org/10.1525/cmr.2015.58.1.97

Publisher: University of California Press

Publisher statement: Published as Kano, L. and Verbeke, A. (2015) The three faces of bounded reliability: Alfred Chandler and the micro-foundations of management theory. California Management Review, 58 (1). pp. 97-122. ISSN 2162-8564 doi: $10.1525 / \mathrm{cmr} .2015 .58 .1 .97$. ( 2015 by the Regents of the University of California. Copying and permissions notice: Authorization to copy this content beyond fair use (as specified in Sections 107 and 108 of the U. S. Copyright Law) for internal or personal use, or the internal or personal use of specific clients, is granted by the Regents of the University of California for libraries and other users, provided that they are registered with and pay the specified fee via Rightslink ${ }^{\circledR}$ or directly with the Copyright Clearance Center. 
All outputs in CentAUR are protected by Intellectual Property Rights law, including copyright law. Copyright and IPR is retained by the creators or other copyright holders. Terms and conditions for use of this material are defined in the End User Agreement.

\section{www.reading.ac.uk/centaur}

\section{CentAUR}

Central Archive at the University of Reading

Reading's research outputs online 


\title{
The Three Faces of Bounded Reliability: Alfred Chandler and the Micro-Foundations of Management Theory
}

by

\author{
Liena Kano * and Alain Verbeke**
}

\author{
*Assistant Professor of Strategy \\ Haskayne School of Business, \\ University of Calgary, \\ Calgary, Alberta, T2N 1N4, Canada \\ Email: liena.kano@haskayne.ucalgary.ca \\ Tel: (403) 220-2993 \\ Fax: (403) 282-0095 \\ **Professor of International Business Strategy \\ McCaig Chair in Management \\ Haskayne School of Business, \\ University of Calgary, \\ Calgary, Alberta, T2N 1N4, Canada \\ Email: averbeke@ucalgary.ca \\ Tel: (403) 220-8803 \\ Fax: (403) 282-0095
}

And Adjunct Professor, Solvay Business School, University of Brussels (VUB),

Belgium

And Alan Rugman Memorial Fellow, Henley Business School, University of Reading, United Kingdom

An earlier version of this paper was presented at the 2013 Academy of Management Meetings in Orlando, Florida. It was the recipient of the John F. Mee Award for the Management History Division's Best Contribution.

Acknowledgement: The authors are grateful to Joel Bothello, Kim Eddleston, Robert Freeland, Marie-Laure Djelic, Joe Mahoney, Mary O'Sullivan, James Robertson and Richard Rumelt for their insights and comments on an earlier version of the present paper.

Keywords: Alfred Chandler, micro-foundations, behavioural assumptions, bounded reliability, opportunism, safeguards 


\title{
The Three Faces of Bounded Reliability: Alfred Chandler and the Micro-Foundations of Management Theory
}

\begin{abstract}
Alfred Chandler, the celebrated business historian, provided detailed descriptions of both the reasons for failed human commitments and the managerial tools to prevent/remediate such failings, in the context of a growing business firms. Chandler's historical narrative allows identifying three distinct 'faces' of bounded reliability (BRel), including conventional opportunism, as the main drivers of commitment failure. It also suggests a corresponding, 'Cerberus-type' approach to managerial action. Adopting BRel as a micro-foundation in management studies will raise the quality and relevance of scholarly recommendations to improve managerial decision-making and action, because analysis of BRel challenges closely mirrors the real-world problems facing practicing managers.
\end{abstract}

\section{INTRODUCTION}

Realistic behavioural assumptions or micro-foundations play a pivotal role in any theory that claims managerial relevance. As Simon famously pointed out, "nothing is more fundamental in setting our research agenda... than our view of the nature of the human beings, whose behaviour

we are studying. It makes a difference, a very large difference, to our research strategy." Microfoundations are thus important for theory building and testing, but they are also critical for guiding managerial practice. Here, adopting realistic behavioural assumptions can guide managers to make better decisions and to engage in better implementation of a planned sequence of actions, thereby achieving better outcomes.

Much management research draws upon two core assumptions about the behaviour of economic actors - bounded rationality and some strong form of self-interest. ${ }^{2}$ In particular, economics-based management theories such as transaction cost economics (TCE) assume self- 
interest akin to opportunism, a concept popularized by Oliver Williamson, TCE's main advocate and one of the theory's two intellectual fathers (the other one being the late Ronald Coase). ${ }^{3}$ Opportunism can be defined as "self-interest seeking with guile" or "calculated efforts to mislead,

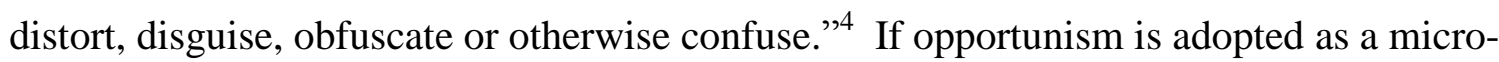
foundation, then purposive managerial decision-making and action should be guided by the need to safeguard against economic actors' potential opportunistic behaviour.

While Williamson has been called "the most sophisticated student of opportunism", and TCE has been characterized as an "opportunism-based" theory, ${ }^{5}$ variations of this microfoundation have been adopted and explored far beyond Williamson's original application in the context of structural governance choices, such as the choice between arm's length contracting and internalization. Opportunism as a variable or assumed micro-foundation appears in a wide range of studies in multiple management sub-disciplines and functional settings, from marketing, entrepreneurship, organizational dynamics, operations, and international business, to ethics, law and public policy. ${ }^{6}$ The context in which opportunism is invoked has broadened from the wellunderstood Williamsonian puzzle of selecting the best available governance structure, to a wide range of applications, including the dynamics of ongoing relationships among a variety of actors engaged in economic exchanges, such as business partners, family members, employees, contractors, competitors, and government agencies. ${ }^{7}$

Yet, the relevance of the opportunism assumption has been much debated. ${ }^{8}$ Opportunism has been criticised for its narrow conceptual focus, for having earned only scarce and inconclusive empirical support, and, broadly speaking, for its inaccurate portrayal of human nature. ${ }^{9}$ It has been argued that the assumption of unbounded self-interest is as unrealistic as the neoclassical assumption of unbounded rationality, rejected by management scholars in favour of the bounded rationality construct. ${ }^{10}$ Most importantly, it has been argued that propagating 
opportunism as the essential micro-foundation to guide managerial decision-making and action actually creates 'bad' management practices and - paradoxically - destroys the moral fibre of business. ${ }^{11}$ Scholarly attempts to uncover ways of curbing opportunism, either ex ante or ex post, have yielded a rather limited toolbox of mechanisms, consisting mainly of contractual safeguards, incentive alignment, monitoring and - perhaps paradoxically - the development of 'trust.' 12 The problem with this toolbox is that it still leaves firms vulnerable to commitment breakdowns due to behavioural drivers other than opportunism.

We view the envelope-concept of bounded reliability (BRel), first introduced by Rugman and Verbeke, as a more appropriate micro-foundation for studying the behaviour of economic actors. ${ }^{13}$ BRel refers to economic actors being reliable, but only boundedly so (similar to bounded rationality referring to economic actors being rational, but only boundedly so). BRel can be defined as imperfect effort to make good on open-ended commitments, either because of opportunism or because of two other reasons. First, benevolent preference reversal, which often occurs in a systemic fashion, with the same individuals engaging in repeated, dysfunctional preference reversals (thereby suggesting that the challenge at hand encompasses more than a mere information problem), but without guile playing a significant role. ${ }^{14}$ Second, identity-based discordance, which means that in spite of individuals' stated or assumed commitments, they maintain contradictory behaviour in line with their personal identity or with past, prevailing practices they identify with.

The BRel concept is relevant especially when addressing the micro-level detail of decision-making and action in the form of managerial practices or routines, deployed within a broader governance system that guides relationships among economic actors inside the firm and with outside stakeholders, such as suppliers, distributors, other types of contracting partners, and organizations in the non-market sphere. ${ }^{15}$ BRel can be used to assess the relative efficiency and 
effectiveness of these managerial practices, whereas opportunism, being a more limiting microfoundation with a narrow toolbox to prevent its occurrence or to mitigate its negative consequences, would fail to address any 'good faith' commitment failures.

The first objective of this article is to develop the BRel concept further, by exploring behavioural elements, in addition to - or as a substitute for - opportunism. BRel provides a comprehensive framework for the treatment of failed commitments, but it is a relatively new, multifaceted concept requiring further conceptual development and refinement. BRel has been invoked in several studies in international business and entrepreneurship, and now requires further contextualization in the more general areas of strategy and general management. ${ }^{16}$

Given the above, this article's second objective is to investigate more thoroughly the multiple facets of BRel in a very specific managerial setting. Here, we will focus on insights from the oeuvre of Alfred Chandler, the late business historian. Specifically, we revisit Chandler's classic history of the Du Pont and General Motors Company (GM) corporations. ${ }^{17}$ Our choice of this historical context was targeted. Alfred Chandler has been called "the most influential business historian of the twentieth century" and has been lauded for "almost inventing the field of strategic management." ${ }^{18}$ His monumental works, Strategy and Structure, Pierre S. Du Pont and the Making of the Modern Corporation, The Visible Hand and Scale and Scope, have become foundational pieces of modern management thinking. ${ }^{19}$ Importantly, for the purpose of our study, Chandler's work served as one of the original sources for TCE theory development in the context of large-firm governance, with opportunism as one of the theory's two micro-foundations (the other one being the widely accepted bounded rationality concept).

It has been argued that history can help management scholars and practitioners understand the nature and context of contemporary problems, forecast trends, refine knowledge, and interpret the present. ${ }^{20}$ In this study, we draw a lesson from history by examining Chandler's narrative on 
the 'making of the modern corporation', i.e. the transformation of the Du Pont Corporation and GM from loosely run family businesses to modern industrial corporations. We try to understand better the managerial implications of this classic work of business history, using BRel as a novel management theory lens.

The remainder of the paper is structured as follows. First, we include a brief background on the scholarly discussion surrounding appropriate micro-foundational assumptions of management theory, with a focus on BRel as the envelope of behavioural drivers to explain failed managerial commitments. Second, we provide further discussion of our data source and give an overview of our methodology. Third, building upon Chandler's historical analysis, we present a comprehensive model of BRel, whereby we distinguish between opportunism and two other faces of BRel. We show how all three BRel faces - as well as the managerial tools to manage them are relevant to explaining the 'making of the modern corporation'. We conclude with discussing the implications of the multiple dimensions of the BRel concept as an appropriate microfoundation for management research associated with an extensive toolbox for managers.

\section{MICROFOUNDATIONS OF MANAGEMENT THEORY: OPPORTUNISM VERSUS}

\section{BOUNDED RELIABILITY}

Given the above-mentioned questions surrounding the accuracy, completeness and even relevance of the behavioural assumption of opportunism, social scientists have engaged in exploring a variety of alternatives. Yet, in spite of a surge in the study of multiple expressions of bounded rationality (including, inter alia, the rich work on prospect theory), ${ }^{21}$ no alternative to or extension of - opportunism has made credible inroads into the management literature. In their pioneering article on a behavioural approach to law and economics, Jolls et al. introduced bounded willpower and bounded self-interest as complements to the assumption of bounded rationality, but these constructs do not capture in a comprehensive fashion non-fulfillment of 
commitments in an organizational setting, nor have management scholars adopted them as alternatives to opportunism. ${ }^{22}$

Trust has been put forward as an alternative assumption to explain and guide managerial decision-making and action in particular situational contexts, but we do not view trust as a proper micro-foundation for management studies. Williamson himself has always viewed trust as a nonstarter: the view that individuals should be considered inherently trustworthy or that the engineering of trust in organizational settings can achieve this same outcome (as in: 'trust me that I will make good on my commitments'), is considered naïve or myopic in the absence of other safeguards and unnecessary in the presence of such safeguards. ${ }^{23}$ Further, there is no clear, unambiguous relationship between higher trust and the level of achieving desired outcomes of an exchange. On the contrary, higher trust unaccompanied by credible safeguards implies higher vulnerability of at least one party to the exchange, and therefore unwanted exposure to the dark side of trust. ${ }^{24}$ In addition, even in a fully trusting environment, and without any strong form of self-interest, there can be an abundance of failed commitments.

We view BRel as one of the most significant extensions of credible micro-foundations for management theory, beyond refinements to the bounded rationality concept. As noted above, BRel explains non-fulfillment of commitments even in the absence of intentional deceit (but beyond the mere lack of technical competences or the dominance of unpredictable and uncontrollable environmental changes). Bounds on reliability can take the form of opportunism, but also - and more commonly - of benevolent preference reversal and identity-based discordance vis-à-vis agreed upon goals, courses of action, and allocation of resources to achieving these goals ${ }^{25}$.

Understanding good-faith sources of commitment failure can assist in designing appropriate mechanisms to prevent or correct such failures without invoking value-laden and 
often inaccurate concepts such as breach of trust (betrayal) or dishonest behaviour (cheating). In terms of managerial practices described in extant literature, the mechanisms to prevent or correct expressions of BRel are significantly broader than those employed to curb opportunism, and can include realistic formal goal-setting, regular reviews of targets, cultivating informal connections among actors working on interrelated activities, developing clear roadmaps to implement projects, joint planning by different hierarchical levels in the organization, frequent budgetary reviews and setting limits on the size and scope of new activities. ${ }^{26}$

\section{DATA AND METHODOLOGY}

\section{Historical case study: Pierre Du Pont, Chandler and Williamson}

Pierre S. Du Pont and the Making of the Modern Corporation is a well-known, detailed account of the functioning of various parts of the Du Pont and GM corporations, written from the point of view of Pierre Du Pont, a critical force behind both corporations' unprecedented growth and

success and arguably America's "single most influential executive." ${ }^{, 27}$ Chandler's historical study covers almost 130 years, from the time Pierre Du Pont's great-great-grandfather founded the Du Pont Company in 1799, until the end of Pierre's active business career, marked by his resignation from GM's board in 1928. Chandler himself referred to his book as "the story of a man rather than of a firm," arguing that "a study of a businessman rather than a business firm has the advantage of permitting a sharp focus. It makes possible an exploration and an analysis of complex business activities, processes and decisions in a shorter space... ${ }^{, 28}$ Pierre was involved in the Du Pont Corporation, his family's business, from the early 1900s, first as a treasurer, and eventually as the company's President. At GM, Pierre entered the scene at a time of crisis, and helped reverse the company's fortune through his leadership as an influential shareholder, Board member, President and Chairman. While the circumstances of Pierre's involvement in the two corporations are different, the relevant commonality is that under his guidance, both companies 
were transformed into professionally managed, technologically advanced corporations, and, importantly, the largest and most powerful international competitors in their respective industries.

We chose this particular book among Chandler's writings for three reasons. First, the focus on one individual's exchanges with a wide variety of economic actors provides an appropriate setting for exploring realistic micro-foundations of management theory.

Second, Pierre S. Du Pont and the Making of the Modern Corporation is the least known but the most personal of Chandler's four masterpieces. Strategy and Structure, The Visible Hand, and Scale and Scope have been widely celebrated and analyzed ${ }^{29}$ while Pierre S. Du Pont and the Making of the Modern Corporation garnered significantly less scholarly and public attention. However, Chandler's family was tightly intertwined with the Du Pont family and the Du Pont Corporation for decades. Chandler's great grandmother was raised by the Du Ponts after the death of her parents, and his great grandfather was William G. Ramsay - the first chief engineer of E. I. Du Pont de Nemours Chemical Company, prominently featured in the book. This personal connection makes Chandler's story particularly compelling in terms of the depth of insight embedded in the analysis.

Third, Chandler's work, as mentioned above, inspired Williamson's comparative analysis of functionally organized (unitary or U-form) and multi-divisional (M-form) companies in terms of their fit with particular external environments and internal strategic requirements. Williamson's interpretation of Chandler's oeuvre is that the M-form, as a governance mechanism with bounded-rationality-economizing properties, also supported curbing opportunism in multiproduct, multi-market strategy settings. The M-form attenuates sub-goal pursuit by functional departments, prevailing in the U-form enterprise. ${ }^{30}$ In the present paper, our interest is not to revisit the comparative efficiency of the two governance structures in specific situational contexts, but rather to assess whether Chandler himself assumed a strong form of self-interest. Chandler 
did not explicitly embrace any particular behavioural assumption, which is consistent with the general tendency of most historical records to omit motivations. ${ }^{31}$ In fact, Chandler was concerned mainly with accurately describing organizational change processes, rather than with crafting a parsimonious conceptual explanation of such organizational change, a point also powerfully made by Jones and Khanna on the importance of Chandler's oeuvre for the management field. ${ }^{32}$ Williamson's interpretation of Chandler's work, with the need to curb opportunism as a critical driver of organizational transformation, would therefore appear to be somewhat overly parsimonious, an often-observed hazard when the work of a business historian is used by social scientists. ${ }^{33}$

Not surprisingly, our analysis of Chandler's work suggests he espoused a much broader view of human nature than opportunism, more closely aligned with the BRel perspective. During their transition from family businesses to professionally managed, diversified enterprises, firms such as Du Pont and GM were bound to encounter many challenges that had a human dimension: conflicts between personal and impersonal values, business' intrusion on kinship, a need to cope with changes in previously successful managerial practices, a requirement to build capacity to process new information and to absorb new ways of doing business, are but a few problems encountered by employees and managers of Du Pont and GM in their journey toward professionally managed, diversified corporations. Many of these problems are related to bounded rationality, and some indeed to opportunism, which triggered failed commitments. However, as we will show below, malevolence is insufficient as a generalized explanation of such failures. Chandler de facto described other important behavioural drivers of failure.

It should be noted that Chandler himself suggested that his case study descriptions could be used as a basis for management theorizing. ${ }^{34}$ Our specific focus is on the divergence between a narrow, opportunism-based interpretation of the functioning of large, diversified firms, and what 
we consider Chandler's own interpretation. We therefore do not make claims about objective reality, but rather, in accordance with a more subjectivist worldview appropriate for inductive research, about Chandler's interpretation of reality. We recognize that Chandler had a rather personal story to tell. This story, however, is informed by the business historian's focus on the micro-level detail of managerial practice, and it allowed us to identify the context and reasons for several instances of broken promises. It provided insight, from Chandler's perspective, into which micro-foundations composing the 'nature of man' affect managerial practices and outcomes.

\section{Theory building}

We followed a five-task sequence for theory building through historical analysis. ${ }^{35}$ The first task is case selection, discussed in detail above. The second task is constructing, whereby we adopted the prior conceptualization of BRel by Verbeke and his co-authors as a starting point, to develop a broad, multifaceted concept with high explanatory power. The third task includes collecting and appraising source material, referring in this case to our initial reading of the text to ensure sufficient level of detail to enable our analysis. The fourth task is engaging iteratively in analysis and narrative. Here, we adopted elements of the grounded theory approach, but deviated from pure-play inductive research to a form of 'abductive' inquiry, meaning that data and extant theory were considered simultaneously. ${ }^{36}$ Specifically, we searched for patterns in the behaviour of economic actors that explained failed commitments.

Using emergent coding, we looked for distinct dimensions of BRel in terms of patterns of managerial behaviour explaining non-fulfillment of commitments. We grouped each set of related examples into an emerging dimension of BRel, and further categorized related examples into distinct overarching faces of BRel, thereby identifying three faces, each having two dimensions: opportunism (consisting of ex-ante and ex-post opportunism), benevolent preference 
reversal (consisting of reprioritization and scaling back on overcommitment), and identity-based discordance (consisting of regression and divided engagement). ${ }^{37}$ The three-faced model of BRel is shown in Figure 1.

We used a special sub-category of content related to safeguarding against the three faces and six dimensions of BRel, i.e. instances of managerial behaviour directed at preventing or mitigating each type of commitment non-fulfilment. We coded such instances of safeguarding and conducted a comparison across categories to identify differences and similarities in safeguarding practices tied to each specific BRel dimension, as shown in Table 1.

The fifth and last task in theory building is results evaluation. Here, we created our broad model of BRel consisting of the three faces and six dimensions, with distinct safeguarding mechanisms and behaviour drivers associated with each. We then applied our framework to the entirety of Chandler's text to confirm that our conceptualization fits plausibly with his story. Finally, we told our own story of how the three faces of BRel fit together, how they fit with Chandler's description of the making of the modern corporation, and, most importantly, how they remediate the limiting opportunism assumption.

\section{RESULTS AND DISCUSSION}

As noted above, our analysis revealed three main behavioural patterns related to failed human commitments. In this section, we describe concrete examples of these three faces in Chandler's work, in line with Figure 1.

\section{INSERT FIGURE 1 ABOUT HERE}

\section{Opportunism}

Predictably, incidents of both ex-ante and ex-post opportunism were found in Chandler's historical account. 
Ex-ante opportunism. A notorious antitrust lawsuit against Du Pont, instigated by a former employee, offers an example of ex-ante opportunism. ${ }^{38}$ Robert Waddell, a former Dupont salesman, had resigned from the company to start his own operations. Having gained independence from Du Pont -with the latter expecting 'fair' competitive behavior typical for industry rivals - Waddell launched a crusade against Du Pont, fully guided by self-interest seeking with guile. He accused the firm of monopolizing the market and using unfair competitive tactics to drive smaller players out of business. Wadell's motivations from the outset were to win a personal vendetta against Du Pont and to collect damages should his own company be 'proven' a victim of unfair competition. Waddell's attack relied on a multitude of distorted facts and false premises (e.g., stating that Du Pont was selling at a loss for the purpose of destroying competitors; deliberately and falsely portraying Senator Henry A. du Pont as Du Pont Company’s head to create negative publicity; accusing Du Pont of a plan to extort the government, etc.). It serves as an example of premeditated, ex-ante opportunism by an economic actor whose only relationship with Du Pont at the time of the lawsuit was that of being a competitor, and whose main goal was to extract money from Du Pont, through the use of the court system.

Ex-post opportunism. As one example, during the economic downturn of 1907, Du Pont's longstanding supplier of one of its most critical inputs - nitrate of soda - used Du Pont's position of dependency to demand a change of contract on very short notice. The supplier requested deposit of collateral, which had not been a part of the prior arrangement. After the request was granted, the supplier made additional demands, insisting on obtaining exclusivity of all Du Pont's transactions and imposing additional requirements about the deposit of collateral. Chandler interprets the supplier's demands - described by Pierre Du Pont as “obnoxious" - as a manifestation of strong-form self-interest. ${ }^{39}$ The supplier used exogenous circumstances - a 
severe financial crisis - and the business partner's resulting high asymmetrical dependence on the supplied product to renege on prior commitments in order to achieve financial gain.

\section{Benevolent preference reversal}

Reprioritization. This BRel dimension means delaying a commitment to a course of action in favour of pursuing other opportunities, which may offer a higher - or more immediate - probable payoff. Such discounting of original commitments can push the decision maker to postpone the fulfillment of a commitment to the point where such a commitment can no longer be fulfilled. ${ }^{40}$ While prior work on reprioritization has focused on instances where actors simply delay commitments rather than dismiss them, our analysis uncovered a different type of reprioritization, whereby original commitments were abandoned. We can thus distinguish between reprioritization leading to postponed commitments versus cancelled commitments. ${ }^{41}$

One key example of reprioritization, though lacking long-term dysfunctional effects on the firm, can be found in Coleman Du Pont's (cousin of Pierre Du Pont and President of the Du Pont company) reversal of his commitment to build a highway to run from Wilmington to Maryland, made initially in $1911 .^{42}$ The proposed road was supposed to generate positive reputational effects for the firm and externalities, in allowing Wilmington, where the firm's head office was located, to grow in parallel with the company. Coleman planned to finance the road construction himself, and subsequently to donate the highway to the people. The commitment was one in a series of political moves aimed at enhancing not only Du Pont's but also Coleman's personal reputation with external stakeholders, as at the time he had serious political ambitions as a member of the Republican Party. Unfortunately, the highway construction had to be suspended due to predictable difficulties encountered with downstate farmers who were asked to sell land for a right of way. For a while, Coleman focused on other priorities, thus disappointing a number of stakeholders. It was not, however, an opportunistic abandonment of a promised set of actions 
made to the city of Wilmington and the public. In this case, the commitment was merely postponed, and construction resumed in 1926. Here, the divergence from the promised pattern of actions was only temporary.

Chandler does, however, also describe situations where the revision of initial goals and commitments, in favour of a conflicting set, led to full abandonment of the original commitments. In extreme cases, decision makers may redefine (expand or simply swap) the moral circle of actors whose interests supposedly matter regarding a particular issue; the interests of the original circle thus become invalidated. ${ }^{43}$ Pierre Du Pont's purchase of his cousin Coleman's shares, aimed at obtaining full control of the company illustrates this form of reprioritization.

"Pierre and his five associates conducted their negotiations with Coleman and their final purchase of his stock with great speed and in absolute secrecy," meaning without informing Pierre's other cousins, Alfred and William Du Pont, or the other members of the Executive Committee, who would certainly not have permitted the transaction had they had any knowledge of it. ${ }^{44}$ From Alfred and William's viewpoint, the move was a breach of faith, marking the beginning of a conflict that eventually split the family. Considered from the perspective of respecting family-based corporate governance, it could be seen as an act of opportunism. ${ }^{45}$ Chandler, however, offers a different angle. "If Pierre was to stay in," - he writes, - "if he was to be responsible for the future of the Powder Company, he wanted the necessary authority to carry out this responsibility. ${ }^{, 46}$ Further, Pierre Du Pont wanted to give key executives a substantial claim on the company's profits, following his belief that "the success of a modern large corporation depended on making its executives 'partners' in the business by permitting them to consider themselves owners as well as managers" ${ }^{\prime 47}$ - a move that, in Pierre Du Pont's view, would only be possible through his purchase of Coleman's stock. We have, therefore, a situation whereby conflicting goals prompted reprioritization that could be considered opportunistic in 
relation to some goals, but well intended in relation to other ones. Chandler himself suggests the lack of malevolence. Pierre Du Pont felt that "he had to choose between the needs of the enterprise and the continuance of family solidarity." ${ }^{48}$ Remaining true to his vision of the company, he knowingly reneged on his prior commitment to preserving harmony among family clans. He traded off his commitment to Alfred and William for a commitment that he deemed more important - the commitment to "the future of the Powder Company." ${ }^{, 9}$ The moral circle of the family was traded for an expanded moral circle of those affected by the future of the corporation, deemed a more important priority. Pierre Du Pont was therefore unreliable in terms of his efforts to make good on his commitment towards family members that he would respect and strengthen family-based governance.

Overcommitment. This BRel dimension refers to instances of ex-ante selection of too many commitments that have to be scaled back ex-post. ${ }^{50}$ This phenomenon accounts for a considerable portion of non-fulfillment of promises in Chandler's narrative. One example can be found in the way GM was managed prior to Pierre Du Pont becoming involved with the company in 1915. GM's founder and President, William C. Durant, ran the company in a "fast-moving, freewheeling manner," without much financial or administrative control. ${ }^{51}$ Durant insisted on being personally involved in all intricacies of the company's operations and systematically overestimated his ability to single-handedly control the complex corporation, without much method or system, without an adequate decision-making body and without active involvement of the Board. Here, Durant's pattern of actions can be seen as an uncodified managerial practice adopted in the organization. As a result, the company ended up in a financial crisis and was unable to meet its obligations to shareholders. Some of the problem is clearly related to bounded rationality (i.e. the natural limits of Durant's knowledge on various functional aspects of the business), but the President's systemic overconfidence in his ability to manage the corporation in 
the absence of proper governance support and without much reliance on specialized expertise in functional areas was at the heart of the issue.

GM's Executive Committee's decision to cancel a copper-cooled engine program in 1922 is another illustration of overcommitment. ${ }^{52}$ Substantial resources and time had been committed to developing this important innovation. Pierre Du Pont, who was inspired by the innovation and foresaw a great future for it in the automobile industry, actively pushed producing the new engine. However, he overestimated the company's ability to develop, test and refine the engine in time to meet production deadlines. Part of the problem is again related to bounded rationality, but the overcommitment was further fuelled by clearly unrealistic promises of R\&D and production managers, who were unable to meet their respective schedules. In the end, the combination of overcommitment at different levels in the organization led to the engine's market failure: the newly engineered engine performed poorly, and the market's reception of copper-cooled cars was unfavourable. The Executive Committee decided to refocus on an expansion program for Chevrolet instead of the further development of the copper-cooled engine, to the great disappointment of Pierre Du Pont and Charles Kettering, GM's engineer in charge of R\&D. Kettering attributed this preference reversal to "an organized resistance within the

Corporation." 53 However, our reading of the case suggests that it was management's overestimation of the company's ability to produce the innovation in the set timeframe that drove the reversal.

\section{Identity-based discordance}

This category of BRel refers to commitment non-fulfillment due to conflict between 'what one promises' (in good faith) and 'what one represents' or 'values' in terms of one's identity. More specifically, economic actors commit to a course of action in good faith, yet deviate from this agreed-upon course in a way that manifests itself over time. Unlike the case of benevolent 
preference reversal, neither a shift in timing of delivering on the commitment takes place, nor an adjustment of the commitment itself. Rather, the conflict between promise and identity becomes apparent over time and leads to some disconnect between the promised actions and the realized, identity-driven actions, resulting in a breach of contract or unfulfilled promises. We observed two types of identity-based discordance: 1) internal psychological conflict, whereby individual actors identify with processes, routines and strategies - often vestiges of a successful past - that contradict stated or assumed commitments towards leaving behind this past; and 2) inter-group conflict, whereby individuals operating in particular units (either inside the firm or being associated with external contracting parties), identify with and pursue appropriate 'local' goals that are misaligned or conflict with those of others, in a way that ultimately diminishes achieving 'global' (firm-level) goals. Based on the above observations, we identified two facets of identitybased discordance: regression and divided engagement.

Regression. This phenomenon is associated with organizational change, and refers to abandoning agreed upon commitments due to a cognitive ambivalence to change, and the persistent attachment, good-faith but also dysfunctional, to existing (pre-change) practices. ${ }^{54}$ Classic organizational research on identity and change suggests that individuals" perceptions of "who they are and what they stand for" are a strong factor in their commitment (or lack thereof) to organizational action. $^{\mathbf{5 5}}$

Chandler's narrative addresses the making of the modern corporation with a focus on two processes of massive change. First, the metamorphosis of the Du Pont company - from a family partnership to a professionally managed firm, and then from a U-form to an M-form corporation. Second, the transformation of GM from a disjointed, loosely run company, to one of the largest and most successful enterprises of its era. In the course of these transformations, tensions often arose and commitment failures occurred due to people's regression to pre-change practices, 
which is important to distinguish from a strong form of self-interest. Mintzberg, for example, cautions against confusing barriers to organizational learning with opportunism by identifying four different psychological sources of resistance to a new strategy: narrow-mindedness (extreme attachment to traditional ways), small-mindedness (lack of understanding of the new strategy), bloody-mindedness (general unwillingness to comply) and right-mindedness (desire to serve the organization in the best possible way). ${ }^{56}$ If we were to reinterpret Mintzberg's classification in our micro-foundational terms, small-mindedness would likely represent an expression of bounded rationality, bloody-mindedness could be akin to opportunism, while narrow-mindedness and right-mindedness could be seen as expressions of regression, referred to below as narrowminded and right-minded regression.

These two forms of regression are typically labeled as 'resistance to change' in the psychology and organizational behaviour literature ${ }^{57}$ First, narrow-minded regression could be described as genuine difficulties in unlearning. ${ }^{58}$ Extant research has identified a number of psychological antecedents of this form of regression, including routine seeking, emotional response to imposed change, cognitive rigidity, and short-term focus. ${ }^{59}$ In our case, regression mainly appeared as the inability to unlearn managerial practices that prevailed in the pre-change era, because of the mere, identity-related "force of old habit." ${ }^{60}$ Consider the following examples:

"The extent that this is now done on the part of [Harry Haskell and Hamilton Barksdale Du Pont's senior executives], it is not with intent but from force of old habit, and it will be some time before the two of them get straightened out, ${ }^{, 61}$ - wrote Arthur Moxham (member of the Executive Committee) to Coleman Du Pont (then President) in 1903 of difficulties experienced in implementing a new organizational structure, according to which senior executives were to keep their attention on broad overall policy and leave operational details to department heads. Haskell and Barksdale, both members of Du Pont's Executive Committee, professed to comply with the 
new arrangement, but in reality could not abandon their old ways, continuing to attend to minute matters in their departments and failing to focus on more important duties. No self-interest was pursued through these actions: they simply appeared unable to unlearn their old behaviour. Their outdated knowledge and dysfunctional attachment to related managerial practices prevented them from obtaining new knowledge and discarding outdated routines. ${ }^{62}$ This case represented more than just a bounded rationality challenge. Formal acceptance of the new managerial practices reflected acknowledgement of their value, yet, over time, commitment to implementing the new practices remained weak and punctured by strong identification with - and regression to - the 'old ways'.

During the 1911-1914 reorganization, Coleman and Pierre Du Pont attempted to separate explicitly long-range policy making from routine administration. ${ }^{63}$ The objective was to train a new generation of leaders and to allow young executives to rise into key operational jobs while limiting the Executive Committee's role in operational decision-making. Yet, the Executive Committee members found it hard to remove themselves from their former roles. They continued to micromanage operations and interfere with succession planning by preventing the new generation of executives from acquiring general management skills. After three years of unsuccessful struggles to implement the new policy, it became apparent that "the solution lay in a change of men rather than of organization," as "the traditions that had been established for years were so strong that simply drawing an organization chart could not change the company's administration." ${ }^{\text {"64 }}$ The company's succession planning efforts, as well as the smooth functioning of governance mechanisms, suffered as a result of the Executive Committee members' regression to the old order and inability to embrace their new roles.

The 1911-1914 reorganization ended with the "change of men" that allowed Pierre Du Pont to move forward with the desired change of structure and related effective adoption of 
managerial practices. ${ }^{65}$ Only by replacing key internal stakeholders with new ones was the organization able to unlearn. A similar scenario unfolded in a restructuring of GM, when Durant had to resign in order for the reorganization to take place under Pierre Du Pont's guidance. ${ }^{66}$ Interestingly, Pierre Du Pont's own reaction to the deep economic and political changes of the 1930s can be seen as a form of narrow-minded regression and consequent self-initiated change of men. ${ }^{67}$ Unable to grasp the meaning of the external changes he was facing, and to exercise requisite entrepreneurial judgment, Pierre Du Pont responded by removing himself from the business world.

Second, right-minded regression reflects the genuine belief that the old ways were better. In these instances, stated commitments to new goals, courses of action and resource allocation can best be described as ceremonial: actors strongly identify with the previous order and resist implementation, albeit without malevolent intent. We see such resistance as being of a good-faith nature because it is “motivated by individuals'... desire to protect the organization's best interests. ${ }^{68}$ Psychologically, it stems from cognitive ambivalence: individuals’ (genuine) beliefs about proposed change as unnecessary, unimportant or inferior, trigger their regressive behaviour. ${ }^{69}$ It is distinct from bounded rationality, as the proposed new routines can be assumed fully understood and rationally compared with pre-change routines.

Right-minded regression is most evident in Alfred Du Pont's, one of the company's executives prior to the 1914 reorganization, reaction to the proposal by Coleman and Pierre Du Pont: "... [the company] during its existence, thrived under the old plan of organization to a remarkable extent; and ... this success has been due largely to past methods, and not in spite of them." ${ }^{, 70}$ This lack of acceptance of new managerial practices led to a bitter family fight, a lawsuit and Alfred Du Pont's eventual departure from the company. 
Divided engagement. This phenomenon represents a multi-actor performance achievement barrier, whereby various actors in the organization adopt conflicting practices, due largely to poor coordination of goals, incentives and routines (e.g., those prevailing in different functional areas). Goals, incentives and routines typically act as encoders of identities at various levels, i.e. a group level, department/division level, or corporate/firm level. ${ }^{71}$ When actors' identify with group-level goals rather than firm-level ones ${ }^{72}$ they may start working against each other, thus undermining the organizational goals to which they have de-facto committed themselves. Observing other actors engaging in what is wrongly perceived as sabotage, i.e., behaviour intended to adversely affect one's own performance, may in itself constitute a bounded rationality problem, but the significant point is that it can lead to a vicious cycle of increasingly dysfunctional 'group think' and related 'counter-actions.' Here, all actors involved may still perceive that they are pursuing firm-level goals, but the discordance at hand is that the means adopted to achieve these goals now include dismissing, discrediting or even displacing other actors' routines, rather than attempting to coordinate better with these other practices. Divided engagement occurs especially in the presence of different sets of routines adopted by two or more units, which come into conflict with each other over time, even though each routine is meant to serve overall, firm-level goals. Our analysis brought to light several instances of divided engagement, with non-fulfillment of commitment by different parties due to these parties' adherence to divergent managerial practices. This was not an expression of opportunism, since all parties had committed to serving the corporation's best interests, but the managerial practices of these parties were not properly aligned to serve the firm's overall interests.

One example is the divided engagement of two Powder Company departments Purchasing and Inventory - during the financial panic of the early 1900 s. ${ }^{73}$ A study of the company's inventory demonstrated that Du Pont's Purchasing Department's spending was 
undermining the company's short-term financial requirements. The head of the Purchasing Department attempted to capitalize on favourable prices for essential materials during the time of the crisis, which resulted in a large increase in required working capital at the exact time when consumption was dropping, leading to excessive inventories in the Essential Materials Department. The latter Department was aiming to reduce inventory costs, while the Purchasing Department's goal was to reduce the long-term cost of supplies. Conventional management theory would explain this issue by alleged opportunistic sub-goal pursuit by the two managers in order to advance their respective functional departments' interests. However, both managers appeared to believe to be acting in the best financial interest of the firm. Pierre Du Pont, who at the time was the company's treasurer and thus possessed the best knowledge of the firm's financial requirements, had to act as arbitrator between the conflicting routines, and initiated a comprehensive review of the issue in an effort to simultaneously achieve the advantages of largescale, long-term buying and minimum inventories. This review eventually led to Pierre Du Pont's judgment that the firm should integrate vertically. When viewed through a BRel lens, the point of this incident is that both departments failed to help the company achieve its financial goals, mainly because their respective routines led them to engage in 'divided,' rather than harmonized behaviour.

This problem was particularly significant at GM, where divisions traditionally operated independently and with very little cooperation and coordination (the problem eventually remedied by creating interdivisional committees). The discordance resulted in redundancies in product lines, operational difficulties, frequent conflicts between "line and staff men" and, ultimately, non-achievement of financial goals. ${ }^{74}$

The intra-company material transfers at Du Pont in 1904 represent another example of diverging divisional routines resulting in divided engagement. ${ }^{75}$ At the time, Pierre Du Pont was 
establishing new costing and pricing policies, stipulating that interdepartmental billing should be based on costs rather than market prices. If intra-company costs were higher than external market prices, the buying units ended up penalized by having to purchase supplies at greater expense. As the company integrated vertically, it began to control a larger portion of its supplies, and interdepartmental transfers became more common. Pierre Du Pont insisted on charging at cost within the company in order to adhere to proper accounting procedures; consequently, while accounting achieved streamlined processes, other departments suffered losses. In addition, the performance of individual departments could not be easily assessed under the cost system, as it was not immediately apparent which selling units' costs were too high to match current, external market prices. As a result, targets were missed due to inappropriate handling of interdepartmental transfers. Much later, during his tenure at GM, Pierre Du Pont accepted market-based intracompany billing, whereby interdepartmental prices were set through negotiations. This practice, reflecting internal markets, has been identified in the management literature as one of the main coordinating mechanisms in multidivisional firms. ${ }^{76}$

\section{IMPLICATIONS FOR MODERN MANAGEMENT PRACTICE: IMPLEMENTING}

\section{SAFEGUARDS}

Our analysis proposes three distinct faces of BRel, namely opportunism, benevolent preference reversal and identity-based discordance, that result in commitment failure and typically, negative consequences for the firm.

The BRel concept builds on the observation that individuals - even when acting in good faith - often fail to make good on their commitments. Such good-faith failures appear responsible for the bulk of unfulfilled commitments in and around firms. BRel recognizes the

presence of opportunism, but offers additional considerations as to when and why non-fulfillment of commitment is likely to occur, and how it can be mitigated. 
Understanding the nature of failed commitments resulting from good-faith actions is important for managerial practice, particularly in the context of preventing commitment breaches in real-life organizational settings. In this section of the paper, we discuss safeguarding tools described by Chandler, and assess their relevance for modern management practice. Each BRel dimension is tied to specific strategies aimed at reducing its occurrence and its negative impacts, as summarized in Table I. Safeguarding against opportunism and benevolent preference reversal is relatively well researched and understood, ${ }^{77}$ but this is less the case for economizing on identity-based discordance. Hence, we will briefly note the economizing strategies for the former BRel facets, but will then focus mainly on safeguarding against regression and divided engagement - the two dimensions of identity-based discordance - representing the third face of BRel identified in this study.

INSERT TABLE I ABOUT HERE

\section{Safeguarding tools against opportunism and benevolent preference reversal}

In general terms, our reading of Chandler confirmed that:

1) Opportunism can be addressed through the rise of sophisticated contractual safeguards, both inside the firm and in the firm's interactions with outside actors;

2) Reprioritizing and the related bounds on reliability vis-à-vis those to whom promises were made, can be addressed through routines that pertain to joint planning and structured communication involving all actors instrumental to making good on the commitment at hand. In addition, we found that some forms of reprioritization must be addressed by meshing conflicting commitments before conflict actually materializes, which can be achieved through entrepreneurial diplomacy, negotiations and arbitration; 
3) Routines that keep in check individuals' impulsivity and their self-assessment bias, can help avoid the occurrence of overcommitment, and the subsequent need to scale back on it.

\section{Safeguarding tools for identity-based discordance}

Regression. For BRel associated with regression, safeguarding strategies include support for participating parties to unlearn pre-existing, dysfunctional organizational practices. In the context of Du Pont and GM, this was achieved through entrepreneurial activities that included personal leadership, mentorship, relationship building and communication. This approach aimed at motivating people to identify with new routines, educating them on how the altered routines are superior, and managing their impressions of change so as to link individuals' perceptions of self

to their perceptions of proposed actions, in a positive way. ${ }^{78}$ Attempting to eliminate regression manifested itself, in Du Pont's case, in "care and diplomacy in making changes." ${ }^{, 79}$ One key example of such safeguarding mechanism can be seen in Pierre Du Pont's efforts to revitalize GM when he took over from Durant as the company's President. ${ }^{80}$ Pierre Du Pont worked diligently to win the confidence of managers who had worked for Durant with respect and affection, and to restore employees' faith in the company's future. He visited plants, had face-toface meetings with managers and made a point of personally meeting local businessmen and civic leaders in towns where GM plants and offices were located. By doing this, Pierre Du Pont reassured GM staff, executives, suppliers and broader stakeholders that the company would remain solvent and become prosperous again, and that the new management was competent, concerned about employees' well being and willing to learn - that is, he engaged in active 'impression management' to inspire positive commitment and action. ${ }^{81}$ In extreme cases, however, a 'change of men' was required. Those who were unable to identify with the new practices either withdrew or were forced to withdraw from the company. 
One of Chandler's concluding remarks about Pierre Du Pont underscores the importance of safeguarding against regression: "In business matters he never favoured maintaining the status quo. His achievements resulted from an accommodation, not a resistance, to change." ${ }^{\prime 82}$ For Pierre Du Pont, helping others identify with change (thereby safeguarding against regression) became an enabler for creating two of the most successful corporations of his time.

Today, managers have additional powerful safeguards against regression at their disposal. Formal training is commonly deployed to curb regression. ${ }^{83}$ Further, information technology (IT) is seen as a change enabler due to its capacity to aid in collecting, analyzing and sharing relevant information. ${ }^{84}$ Yet, two qualifying points should be made here. First, both scholarly and practicebased evidence shows that successful IT-enabled change requires a balance between hard (structural and technological) and soft (organizational and social) factors ${ }^{85}$ - that is to say, 'soft' safeguards against regression, as practiced by Pierre Du Pont, have not lost their relevance in an era of IT-enabled safeguards. Second, dismissal may sometimes be unavoidable, especially in instances when a quick response to change is a strategic imperative. ${ }^{86}$

Divided engagement. Divided engagement among divisional or departmental actors can be safeguarded against by creating a clear, firm-level identity, encoded in overall objectives and routines, that cascades into organizational units, with subsequent encoding in compatible unitlevel objectives and routine. Implementing such an 'identity cascade', however, is easier said than done. ${ }^{87}$ Du Pont employed formal and informal coordination mechanisms to mesh individuals' firm-level and unit-level identities and activities. Formal mechanisms include the programming active head office involvement, structural coordination bodies, and planning and control. Du Pont and GM adopted such mechanisms in the form of comprehensive reviews, interdivisional committees and internal markets. Interdivisional committees proved particularly effective at GM, where misperceived and uncoordinated differences among divisional routines 
and goals resulted in a dysfunctional discordance. The first interdivisional committee, called a 'General Technical Committee', was struck to bridge the gap between engineering and product development as a response to the copper-cooled engine fiasco. ${ }^{88}$ The General Technical Committee proved successful, and the company followed by setting up similar General Sales, Works Managers and Power and Maintenance committees in 1924. These permanent interdivisional committees with their own staff and funds strengthened the corporation considerably by harmonizing the interests and activities of individuals operating in different departments without impairing their autonomy.

Informal, or person-oriented mechanisms include socialization and targeted development of a common corporate culture, which, in Chandler's case, were exemplified by arbitration and relationship building through personal contacts.

While centralization of decision-making may not always be desirable or achievable in today's business environment, a common theme apparent in the above discussion of safeguards is the use of social coordination methods such as communication and relationship building. Interpersonal dynamics appear as relevant as ever to the functioning of a modern corporation; this further underscores the need for realistic micro-foundations to understand fully what is required to achieve managerial success.

It is also worth noting that while divided engagement is a dimension of identity-based discordance, it could also call managerial attention to firm-level goals and routines, and signal the need for structural change - in the same way as the conflict between Du Pont's Purchasing and Inventory departments in the early 1900 s led to vertical integration. ${ }^{89}$ Today's managers should take manifestations of divided engagement as an opportunity to review both inter-level consistency of goals and routines, and the overall appropriateness and strategic soundness of firm-level objectives, processes and even organizational restructuring. 
To conclude our discussion of managerial safeguards, we should note that the broad spectrum of safeguards addressing the various challenges posed by good faith preference reversal and identity-based discordance will often also curb opportunism. ${ }^{90}$ In contrast, the limited arsenal of safeguards against opportunism such as special contractual clauses, incentive alignment and monitoring, is entirely insufficient to prevent or mitigate the effects of 'good-faith' expressions of BRel. For example, socialization can safeguard against opportunism even if deployed with the purpose of regression management, yet incentive alignment deployed to curb opportunism cannot replace socialization to safeguard against regression. The critical point for managers is therefore that trying to safeguard against opportunism alone, without considering safeguards to manage good-faith preference reversals and identity-based discordance, will lead them to miss a wide range of sources of commitment failure, as well as the instruments to prevent or remediate such failures.

\section{VALUE OF BREL IN VARIOUS SITUATIONAL CONTEXTS: CURRENT IMPLICATIONS AND DIRECITONS FOR FUTURE RESEARCH}

Properly managing BRel is particularly relevant to any firm operating in a complex organizational, technological or environmental setting, where the circle of those affected by a particular decision or commitment is diverse and expandable. Consider the realm of family business. In Chandler's words, "the most critical period in the history of any modern large impersonal corporation comes when the founder or his family have to make terms with the requirements of large-scale enterprise. ${ }^{91}$ The potential conflict between the needs of the family and those of the business may create two clans within the firm with distinct identities, opening the door for both reprioritization and divided engagement: for example, non-economic objectives of family members can lead them to subvert commitments made to the firm and its professional 
managers. ${ }^{92}$ Pierre Du Pont was acutely aware of this conflict between kinship and business and in most cases (except when buying Coleman's Du Pont stock without informing the other cousins Alfred and William) worked to mitigate it - mostly by means of negotiations, arbitration, sensitivity "to other people's feelings" and "care and diplomacy in making changes"; he thereby mitigated the unreliability of others and avoided becoming unreliable himself. ${ }^{93}$

Multinational enterprises face 'multiple embeddedness' associated with home versus host countries, which creates a fertile ground for divided engagement. ${ }^{94}$ One example is that of managerial practices prevailing in the host environment, e.g., in the realm of corruption that may be 'expected' in this environment so as to boost short-term sales, but that will also subvert agreed upon routines prevailing in the home country and even in the entire subsidiary network, thereby endangering the firm's reputation. ${ }^{95}$

The management of regression is relevant to any organization facing drastic change in the face of environmental turbulence. Today, firms face employees' regression in response to mergers and acquisitions, business function outsourcing or offshoring, process reengineering, decentralization, restructuring, divestment, change of leadership and/or ownership and introduction of new strategic initiatives, to name but a few common situations requiring employees to embrace change. Regression as a situational facet of BRel offers new ways of conceptualizing resistance to change, while removing the conventional negative connotation associated with 'resistance' and suggesting a variety of mechanisms relevant to managerial practice. In other words, resistance to change, even when the need for such change has been agreed upon, should not be considered as an expression of opportunism, but may require the deployment of substantial resources for purposes of communication and training. Even if the actors involved in regression appear unable to change and need to be removed from the 
organization, this identity-based dysfunction and the inability to unlearn should not be equated with strong-form self-interest.

The three faces of BRel we identified in the context of two multidivisional corporations, are likely valid beyond the confines of a traditional Chandlerian hierarchy, and can be investigated in any other governance form, including the broad spectrum of contractual arrangements with outside parties. Future research should examine the applicability of identitybased discordance in an inter-firm setting, particularly in situations characterized by contracting with a broad spectrum of actors with diverging priorities and identities, e.g., outsourcing relationships, network governance, stakeholder management, management of a geographically dispersed value chain, etc.

\section{CONCLUSION}

Our study makes two key contributions. First, we provide a substantive rationale for adopting bounded reliability or BRel as a micro-foundation in strategic and general management theory, and we identify three distinct 'faces' (each having two dimensions) of this new concept. BRel represents a major improvement over the often-used opportunism assumption and the limited arsenal of tools supposed to suppress it or to remediate its negative impacts. Adopting BRel as a general micro-foundation in management studies can reverse the 'ideology-based gloomy vision' that individuals are systematically driven by strong-form self-interest. Importantly, by showing that many failures to fulfill commitments in business do not actually result from strong-form self-interest, we provide a new path to 'fix' the bad management theories that have made this wrong assumption and that have destroyed good management practices. ${ }^{96}$ When viewed through a BRel lens, commitment non-fulfillment need not be malevolent. Our paper establishes the foundation for theorizing on BRel, but it also has far-reaching implications for managerial practice. Managers in any firm should systematically craft a three-pronged 
approach - i.e., a 'Cerberus project' - to prevent the occurrence and mitigate the negative impacts of each of the three distinct BRel faces. ${ }^{97}$

Our second contribution is that we engaged in a "transdisciplinary" research project, whereby we revisited and reinterpreted for today's managers one of the most elaborate and credible business history cases ever written. ${ }^{98}$ The past few decades have been characterized as a 'historic turn' in management studies, with both historians and managers advocating the relevance of a historical perspective. ${ }^{99}$ In this context, our study shows that insight from high quality historical accounts of how managers addressed critical, real-world challenges in the past can provide effective solutions to almost identical challenges in today's business world.

The present study is not without limitations. It has focused on one - albeit rich and abundant - source of historical data, in one particular organizational context. Here, the three faces of BRel were identified in the context of two, large multidivisional firms. While we have suggested that the three faces of BRel may stretch far beyond the boundaries of the enterprise as a stand-alone operation, future work needs to examine further the various expressions of BRel and their interrelationships in a variety of contexts, ranging from family firms to large MNEs and hybrid organizations, across industries and stages of organizational development. Here, new dimensions of BRel could potentially be uncovered, possibly through further transdisciplinary research.

Further development of this envelope concept is needed to firmly embed BRel as a standard micro-foundation in management research and practice, in addition - but equal in importance - to the now widely accepted bounded rationality concept. In the present article, we have mined Chandler's work to identify the main sources of BRel; we have revisited Chandler's neglected masterpiece and demonstrated that it still serves as a powerful source of evidence for building and refining management theory. Careful reading of the Du Pont masterpiece indeed 
credibly shows that aligning strategy and structure resulted mainly from sustained entrepreneurial (and subsequently routinized) efforts at reducing the occurrence and negative impacts of the various BRel facets. Du Pont's and GM's successful transformation into professionally managed, Chandlerian hierarchies would not have been achieved by a sole focus on reducing bounded rationality problems and by simply assuming the inevitability of human opportunism.

\section{Endnotes}

${ }^{1}$ Herbert Simon, "Human Nature in Politics: The Dialogue of Psychology with Political Science," American Political Science Review 79, no. 2 (1985): 303.

${ }^{2}$ Herbert Simon, Administrative Behaviour (New York, NY: Macmillan, 1961); Oliver E. Williamson, "The Modern Corporation: Origins, Evolution, Attributes," Journal of Economic Literature 19, no. 4 (1981): 1537-1568; The Economic Institutions of Capitalism (New York, NY: Free Press, 1985); "Opportunism and Its Critics," Managerial and Decision Economics 14, no. 2 (1993): 97-107 and The Mechanisms of Governance (New York, NY: Oxford University Press, 1996).

${ }^{3}$ Ibid,; Ronald H. Coase, "The Nature of the Firm," Economica 4, no. 16 (1937): 386-405.

${ }^{4}$ Williamson, "The Modern Corporation: Origins, Evolution, Attributes," 1545 and The Economic Institutions of Capitalism, 47.

${ }^{5}$ Edward J. Romar, "Globalization, Ethics, and Opportunism: A Confucian View of Business Relationships," Business Ethics Quarterly 14, no. 7 (2004): 665; Kathleen Conner and Coimbatore Krishnarao Prahalad, "A Resource-Based Theory of the Firm: Knowledge versus Opportunism," Organization Science 7, no. 5 (1996): 478.

${ }^{6}$ For examples of such studies, see: Romar, "Globalization, Ethics, and Opportunism: A Confucian View of Business Relationships"; Pablo T. Spiller, "Regulation: A Transaction Cost Perspective," California Management Review 52, no. 2 (2010): 147-158; Russel Coff, "Bidding Wars over R\&D-Intensive Firms: Knowledge, Opportunism, and the Market for Corporate Control," Academy of Management Journal 46, no. 1 (2003): 74-85; Claus Steinle, Holger Schiele, and Tanja Ernst, "Information Asymmetries as Antecedents of Opportunism in BuyerSupplier Relationships: Testing Principal-Agent Theory," Journal of Business-to-Business Marketing 21, no. 2 (2014): 123-140; Stephen J. Carson, Anoop Madhok, and Tao Wu, "Uncertainty, Opportunism, and Governance: The Effects of Volatility and Ambiguity on Formal and Relational Contracting," Academy of Management Journal 49, no. 5 (2006): 1058-1077; Jayne W. Barnard, "Shirking, Opportunism, Self-Delusion and More: The Agency Problem Lives On," Wake Forest Law Review 48 (2013): 745-770.

${ }^{7}$ Bart Nooteboom, "Trust, Opportunism and Governance: A Process and Control Model," Organization Studies 17, no. 6 (1996): 985-1010.

${ }^{8}$ Conner and Prahalad, "A Resource-Based Theory of the Firm: Knowledge versus Opportunism"; Sumantra Ghoshal, "Bad Management Theories Are Destroying Good Management Practices," The Academy of Management Learning and Education 4, no. 1 (2005): 75-91; Sumantra Ghoshal and Peter Moran, "Bad for Practice: A Critique of the Transaction Cost Theory," The Academy of Management Review 21, no. 1 (1996): 37-74; Geoffrey M. Hodgson, "Opportunism Is Not the Only Reason Why Firms Exist: Why an Explanatory Emphasis on 
Opportunism May Mislead Management Strategy," Industrial and Corporate Change 13, no. 2 (2004): 401-418; Alain Verbeke, "The Evolutionary View of the MNE and the Future of Internalization Theory," Journal of International Business Studies 34, no. 6 (2003): 498-504. ${ }^{9}$ Eric W.K. Tsang, "Behavioral Assumptions and Theory Development: The Case of Transaction Cost Economics," Strategic Management Journal, 27, no. 11 (2006): 999-1001; Alain Verbeke and Nathan S. Greidanus, "The End of the Opportunism versus Trust Debate: Bounded Reliability as a New Envelope-Concept in Research on MNE Governance," Journal of International Business Studies 40, no. 9 (2009): 1471-1495.

${ }^{10}$ Christine Jolls, Cass R. Sunstein and Richard Thaler, "A Behavioral Approach to Law and Economics," Stanford Law Review 50, no. 5 (1998): 1471-1550; Simon, Administrative Behaviour.

${ }^{11}$ Ghoshal, "Bad Management Theories Are Destroying Good Management Practices."

12 Sandy D. Jap and Erin Anderson, "Safeguarding Interorganizational Performance and Continuity under Ex Post Opportunism," Management Science 49, no. 12 (2003): 1684-1701; R. Preston McAfee and Marius Schwartz, "Opportunism in Multilateral Vertical Contracting: Nondiscrimination, Exclusivity, and Uniformity," The American Economic Review 84, no. 1 (1994): 210-230. Anoop Madhok, "Opportunism, Trust and Knowledge: The Management of Firm Value and the Value of Firm Management," in Handbook on Trust, ed. Reinhard Bachmann and Akbar Zaheer (Cheltenham: Edward Elgar, 2006): 107-123

13 Alan Rugman and Alain Verbeke, "Towards a Theory of Regional Multinationals: A Transaction Cost Economics Approach," Management International Review 45, no. 1 (2005): 517; Alain Verbeke and Thomas Kenworthy, "Multidivisional vs. Metanational Governance of the Multinational Enterprise," Journal of International Business Studies 39, no. 6 (2008): 940-956; Alain Verbeke, International Business Strategy (Cambridge, Mass.: Cambridge University Press, 2013); Verbeke and Greidanus, "The End of the Opportunism versus Trust Debate: Bounded Reliability as a New Envelope-Concept in Research on MNE Governance."

${ }^{14}$ The word 'benevolent', from Latin 'bene' (well) and 'velle' (to wish), has several meanings, including 'well-meaning' and 'kindly.' Here and henceforth, the term 'benevolent' is used as the opposite of 'malevolent' or 'opportunistic.' The term is meant to emphasize the lack of guile, ill intention, or desire to deceive, but is situational rather than dispositional - that is, 'benevolent' describes an actor's intention related to a particular action rather than the actor's character.

${ }^{15}$ As one example of such practices in the context of firm-level boards, see Sascha L. Schmidt and Matthias Brauer, "Strategic Governance: How To Assess Board Effectiveness in Guiding Strategy Execution," Corporate Governance: An International Review, 14, no.1 (2006): 13-22. ${ }^{16}$ Elitsa R. Banalieva and Kimberly A. Eddleston, "Home-Region Focus and Performance of Family Firms: The Role of Family vs Non-Family Leaders," Journal of International Business Studies 42, no. 8 (2011): 1060-1072; Alain Verbeke and Liena Kano, "Transaction Cost Economics (TCE) and the Family Firm," Entrepreneurship Theory and Practice 34,no. 6 (2010): 1173-1182; "The Transaction Cost Economics Theory of the Family Firm: Family-Based Human Asset Specificity and the Bifurcation Bias," Entrepreneurship Theory and Practice 36, no. 6 (2012): 1183-1205 and "The Transaction Cost Economics (TCE) Theory of Trading Favors," Asia Pacific Journal of Management 30, no. 2 (2013): 409-431.

${ }^{17}$ Alfred D. Chandler and Stephen Salsbury, Pierre S. Du Pont and the Making of the Modern Corporation (New York, NY: Harper \& Row, 1971).

${ }^{18}$ Richard R. John, "Business Historians and the Challenge of Innovation," Business History Review 85, no. 1 (2011): 185; Sidney G. Winter and David J. Teece, "A Conversation with 
Sidney Winter on the Contributions of Alfred Chandler," Industrial and Corporate Change 19, no. 2 (2010): 365.

${ }^{19}$ Discussed in Richard Whittington, "Alfred Chandler, Founder of Strategy: Lost Tradition and Renewed Inspiration,” Business History Review 82, no. 2 (2008): 267-277. See Alfred D. Chandler, Strategy and Structure: The History of American Industrial Enterprise (Cambridge, Mass.: MIT Press, 1977), The Visible Hand: The Managerial Revolution in American Business (Cambridge, Mass.: Harvard University Press, 1977) and Scale and Scope: The Dynamics of Industrial Enterprise (Cambridge, Mass.: Harvard University Press, 1990).

${ }^{20}$ David Hackett Fischer, Historians' Fallacies: Toward a Logic of Historical Thought (New York, NY: Harper \& Row, 1970).

${ }^{21}$ Thomas Hutzschenreuter, Ingo Kleindienst, Florian Gröne and Alain Verbeke, "Corporate Strategic Responses to Foreign Entry: Insights from Prospect Theory," Multinational Business Review 22, no. 3 (2014): 51-60.

22 Jolls, Sunstein and Thaler, "A Behavioral Approach to Law and Economics."

${ }^{23}$ Williamson, The Mechanisms of Governance.

${ }^{24}$ For discussions of trust in management theory, see Anoop Madhok, "Opportunism, Trust and Knowledge: The Management of Firm Value and the Value of Firm Management"; Augustine A. Lado, Rajiv R. Dant and Amanuel G. Tekleab, "Trust-Opportunism Paradox, Relationalism, and Performance in Interfirm Relationships: Evidence from the Retail Industry," Strategic Management Journal 29, no. 4 (2008): 401-423; Nooteboom, "Trust, Opportunism and Governance: A Process and Control Model"; Erin Anderson and Sandy D. Jap, "The Dark Side of Close Relationships," MIT Sloan Management Review 46, no. 3 (2005): 75-82.

${ }^{25}$ Verbeke and Greidanus, in "The End of the Opportunism versus Trust Debate: Bounded Reliability as a New Envelope-Concept in Research on MNE Governance," propose a preliminary model of benevolent preference reversal, consisting of two facets: reprioritization and scaling back on overcommitment. Reprioritization means discounting an original commitment to a course of action in favour of pursuing alternative commitments with a higher or more immediate probability of payoff. Reprioritization has two sources. First, a decision maker may make an ex ante commitment to a course of action considering a high probability of payoff. However, in completing the commitment, other opportunities may arise with a higher probable payoff, at least from the viewpoint of the decision maker, that cause reneging on the original commitment. Second, the cognitive bias known as the time discounting bias makes individuals place a lower value on future events than on more proximate ones. Time discounting bias encompasses any reason for paying less attention about a future consequence, and the related preference for immediate utility over delayed utility. Overcommitment means ex ante good-faith selection of too many commitments that have to be scaled back ex post. Overcommitment stems from the behavioral phenomena of impulsivity and overconfidence, i.e., an unrealistic belief in one's own abilities, predictions or chances of success.

${ }^{26}$ Identified in Verbeke and Greidanus, "The End of the Opportunism versus Trust Debate: Bounded Reliability as a New Envelope-Concept in Research on MNE Governance."

${ }^{27}$ Chandler and Salsbury, Pierre S. Du Pont and the Making of the Modern Corporation.

${ }^{28}$ Ibid. ", xix.

${ }^{29}$ For examples, see Barry Supple, "Scale and Scope: Alfred Chandler and the Dynamics of Industrial Capitalism," The Economic History Review 44, no. 3 (1991): 500-514 and Joseph T. Mahoney, Economic Foundations of Strategy (Thousand Oaks, CA: Sage Publications, 2005).

${ }^{30}$ Williamson, "The Modern Corporation: Origins, Evolution, Attributes," The Economic 
Institutions of Capitalism and The Mechanisms of Governance.

${ }^{31}$ Mary Jo O'Sullivan and Margaret B. W. Graham, "Moving Forward by Looking Backward," Journal of Management Studies 47, no. 5 (2010): 775-790

${ }^{32}$ Geoffrey Jones and Tarun Khanna, "Bringing History (Back) into International Business," Journal of International Business Studies 37, no. 4 (2006): 453-468.

${ }^{33}$ O'Sullivan and Graham, "Moving Forward by Looking Backward."

${ }^{34}$ Alfred D. Chandler, "Comparative Business History," in Enterprise and History: Essays in Honour of Charles Wilson, ed. David C. Coleman and Peter Matthias (Cambridge, Mass.: Cambridge University Press, 1984), 3-26.

35 Ingram, Rao and Brian S. Silverman, "History in Strategy Research: What, Why, and How?"

${ }^{36}$ For discussion of grounded theory, see Anselm L. Strauss, Qualitative Analysis for Social Scientists (New York, NY: Cambridge University Press, 1987) and Roy Suddaby, "From the Editors: What Grounded Theory Is Not," Academy of Management Journal 49 no. 4 (2006): 633642; for discussion of abductive inquiry, see Dennis A. Gioia, Kevin G. Corley, and Aimee L. Hamilton, "Seeking Qualitative Rigor in Inductive Research: Notes on the Gioia Methodology," Organizational Research Methods 16, no. 1 (2013): 15-31 and Mats Alvesson and Dan Kärreman, "Constructing Mystery: Empirical Matters in Theory Development," Academy of Management Review 32, no. 4 (2007): 1265-1281.

${ }^{37}$ For coding and grouping, we followed strategies outlined in Juliet Corbin and Anselm Strauss, "Grounded Theory Research: Procedures, Canons, and Evaluative Criteria," Qualitative Sociology 13, no. 1 (1990): 3-20 and Anselm L. Straus and Juliet M. Corbin, "Grounded Theory Methodology: An Overview," in Handbook of Qualitative Research, ed. Yvonna S. Lincoln and Norman K. Denzin (Thousand Oaks, CA: Sage, 1995), 273-285.

${ }^{38}$ Chandler and Salsbury, Pierre S. Du Pont and the Making of the Modern Corporation, 259300 .

${ }^{39}$ Ibid., 219.

${ }^{40}$ On detailed analysis of the sources of reprioritization, see Verbeke and Greidanus, "The End of the Opportunism versus Trust Debate: Bounded Reliability as a New Envelope-Concept in Research on MNE Governance."

${ }^{41}$ In this context, one special case of reprioritization is the occurrence of 'white lies', whereby typically one individual, who is subordinate to another individual, tells the latter 'what he wants to hear', rather than convey an accurate picture of reality. Here, the normally assumed commitment of the subordinate to be truthful in the professional environment where he/she operates is subverted, in some cases because of fear that the bearer of any bad news will be identified with the news itself. The subordinate's original commitment to truthfulness has been replaced by a preference for communicating benign falsehoods.

${ }^{42}$ Chandler and Salsbury, Pierre S. Du Pont and the Making of the Modern Corporation, 326.

${ }^{43}$ Alexander H. Jordan and Pino G. Audia, "Self-Enhancement and Learning from Performance Feedback," Academy of Management Review 37, no. 2 (2012): 211-231.

${ }^{44}$ Chandler and Salsbury, Pierre S. Du Pont and the Making of the Modern Corporation, 335.

${ }^{45}$ Ibid., 336.

46 Ibid., 337.

${ }^{47}$ Ibid., 136.

${ }^{48}$ Ibid., 358.

${ }^{49}$ Ibid., 338. 
${ }^{50}$ For a detailed analysis of psychological sources of overcommitment, which typically also have a bounded rationality driver, see Verbeke and Greidanus, "The End of the Opportunism versus Trust Debate: Bounded Reliability as a New Envelope-Concept in Research on MNE Governance." Importantly, individuals and even groups may engage in systemic reprioritizing and having to scale back on overcommitments, which means that the managerial challenge at hand is not just one related to absence of sufficient information or sufficient information processing capacity per se, i.e., the conventional sources of bounded rationality.

${ }_{51}$ Chandler and Salsbury, Pierre S. Du Pont and the Making of the Modern Corporation, 456.

52 Ibid., 544-546.

${ }^{53}$ Ibid., 544.

${ }^{54}$ Icek Ajzen, “Attitudes," in Wiley Encyclopaedia of Psychology, ed. Raymond J. Corsini (New York, NY: Wiley, 1984), 99-100.

${ }^{55}$ Jane E. Dutton and Janet M. Dukerich, "Keeping and Eye on the Mirror: Image and Identity in Organizational Adaptation," Academy of Management Journal 34, no. 3 (1991): 550/

${ }^{56}$ Henry Mintzberg, "The Design School: Reconsidering the Basic Premises of Strategic Management," Strategic Management Journal 11, no. 3 (1990): 171-195.

${ }^{57}$ We purposefully choose the term 'regression' over 'resistance', and this for three reasons: we avoid negative connotations associated with 'resistance'; we put emphasis on the situational nature of the conflict at hand; we underscore the lack of malevolent intent.

${ }^{58}$ Eric W. K. Tsang, "Organizational Learning and the Learning Organization: A Dichotomy between Descriptive and Prescriptive Research," Human Relations 50, no. 1 (1997): 73-89.

59 Shaul Oreg, "Resistance to Change: Developing an Individual Differences Measure," Journal of Applied Psychology 88, no. 4 (2003): 680-692.

${ }^{60}$ Chandler and Salsbury, Pierre S. Du Pont and the Making of the Modern Corporation, 126. ${ }^{61}$ Ibid.

${ }^{62}$ Bo Hedberg, "How Organizations Learn and Unlearn," in Handbook of Organizational Design, Vol. 1, ed. Paul C. Nystrom and William H. Starbuck (Oxford, Mass.: Oxford University Press, 1981): 3-27; Paul C. Nystrom and William H. Starbuck, "To Avoid Organizational Crises, Unlearn," Organizational Dynamics 12, no. 4 (1984): 53-65.

${ }^{63}$ Chandler and Salsbury, Pierre S. Du Pont and the Making of the Modern Corporation, 314321.

${ }^{64}$ Ibid., 319.

${ }^{65}$ Ibid.

${ }^{66}$ Ibid., 475-491.

${ }^{67}$ Ibid., 590.

${ }^{68}$ Sandy Kristin Piderit, "Rethinking Resistance and Recognizing Ambivalence: A Multidimensional View of Attitudes toward an Organizational Change," Academy of Management Review 25, no. 4 (2000): 785.

${ }^{69}$ Ibid.

${ }^{70}$ Chandler and Salsbury, Pierre S. Du Pont and the Making of the Modern Corporation, 307.

${ }^{71}$ Blake E. Ashforth, Kristie M. Rogers and Kevin G. Corley, "Identity in Organizations: Exploring Cross-Level Dynamics,” Organization Science 22, no. 5 (2011): 1144-1156.

72 Norbert Wiley, "The Micro-Macro Problem in Social Theory, " Sociological Theory 6, no. 2 (1988): 254-261.

${ }^{73}$ Chandler and Salsbury, Pierre S. Du Pont and the Making of the Modern Corporation, 222225. 
${ }^{74}$ Ibid., 528.

${ }^{75}$ Ibid., 151-157.

${ }^{76}$ William G. Ouchi, "A Conceptual Framework for the Design of Organizational Control Mechanisms," Management Science 25, no. 9 (1979): 833-848; Alan M. Rugman, Inside the Multinationals: The Economics of Internal Markets (New York, NY: Palgrave Macmillan, 1981).

${ }^{77}$ Verbeke and Greidanus, "The End of the Opportunism versus Trust Debate: Bounded Reliability as a New Envelope-Concept in Research on MNE Governance."

${ }^{78}$ Dutton and Dukerich, "Keeping an Eye on the Mirror: Image and Identity in Organizational Adaptation."

${ }^{79}$ Chandler and Salsbury, Pierre S. Du Pont and the Making of the Modern Corporation, 499.

${ }^{80}$ Ibid., 509-510.

${ }^{81}$ Dutton and Dukerich, "Keeping an Eye on the Mirror: Image and Identity in Organizational Adaptation," 550.

${ }^{82}$ Chandler and Salsbury, Pierre S. Du Pont and the Making of the Modern Corporation, 604.

${ }^{83}$ Laurence J. Stybel, Robin Cooper and Maryanne Peabody, "Planning Executive Dismissals: How to Fire a Friend," California Management Review 24, no. 3 (1982): 73-80.

${ }^{84}$ Arnoud Franken, Chris Edwards and Rob Lambert, "Executing Strategic Change:

Understanding the Critical Management Elements That Lead to Success," California

Management Review 51, no. 3 (2009): 49-73.

${ }^{85}$ Elinar Iveroth, "Inside Ericsson: A Framework for the Practice of Leading Global IT-Enabled Change," California Management Review 53, no. 1 (2010): 136-153.

${ }^{86}$ Stybel, Cooper and Peabody, "Planning Executive Dismissals: How to Fire a Friend."

${ }^{87}$ Ashforth, Rogers and Corley, "Identity in Organizations: Exploring Cross-Level Dynamics," 1150 .

${ }^{88}$ Chandler and Salsbury, Pierre S. Du Pont and the Making of the Modern Corporation, 547.

${ }^{89}$ Ibid., 222-225.

90 Williamson, "Opportunism and Its Critics," 98.

${ }^{91}$ Chandler and Salsbury, Pierre S. Du Pont and the Making of the Modern Corporation, 357.

92 Verbeke and Kano, "The Transaction Cost Economics Theory of the Family Firm: FamilyBased Human Asset Specificity and the Bifurcation Bias."

${ }^{93}$ Chandler and Salsbury, Pierre S. Du Pont and the Making of the Modern Corporation, 283 and 499.

${ }^{94}$ Verbeke, International Business Strategy.

${ }^{95}$ For a discussion on the dysfunctional effects of corruption, see Elitsa R. Banalieva, Kimberly Eddleston and Alain C. Verbeke, "The Transaction Cost Economics Theory of Trading Favors: The Case of Entrepreneurial Firms," Academy of Management Proceedings Vol. 2013, no. 1. (Academy of Management, 2013).

${ }^{96}$ Ghoshal, "Bad Management Theories Are Destroying Good Management Practices," 82.

${ }^{97}$ Cerberus, in Greek mythology, is a three-headed watchdog of Hades, the lord of the underworld (Encyclopaedia Britannica, http://www.britannica.com/topic/Cerberus, retrieved on 22 June 2015). Like Cerberus needed three heads to effectively guard the underworld to prevent the dead from escaping and the living from entering, managers need a three-pronged approach to fully economize on the three faces of BRel.

${ }^{98}$ Huseyin Leblebici, "History and Organization Theory: Potential for a Transdisciplinary Convergence," in Organizations in Time: History, Theory, Methods, ed. Marcelo Bucheli and R. 
Daniel Wadhwani (Oxford: Oxford University Press, 2014), 79.

${ }^{99}$ R. Daniel Wadhwani, and Marcelo Bucheli, "The Future of the Past in Management and Organization Studies," in Organizations in time: History, Theory, Methods, ed. Marcelo Bucheli and R. Daniel Wadhwani (Oxford: Oxford University Press, 2014), 4; Yair Aharoni, "In Search for the Unique: Can Firm-Specific Advantages Be Evaluated?" Journal of Management Studies 30, no. 1 (1993): 31-49; Steven Kahl, Brian Silverman and Michael Cusmano, History and Strategy (Bingley: Emerald Group Publishing, 2012); O'Sullivan and Graham, "Moving Forward by Looking Backward"; Rao and Silverman, "History in Strategy Research: What, Why, and How?"

Figure 1. The Three Faces of Bounded Reliability (BRel)

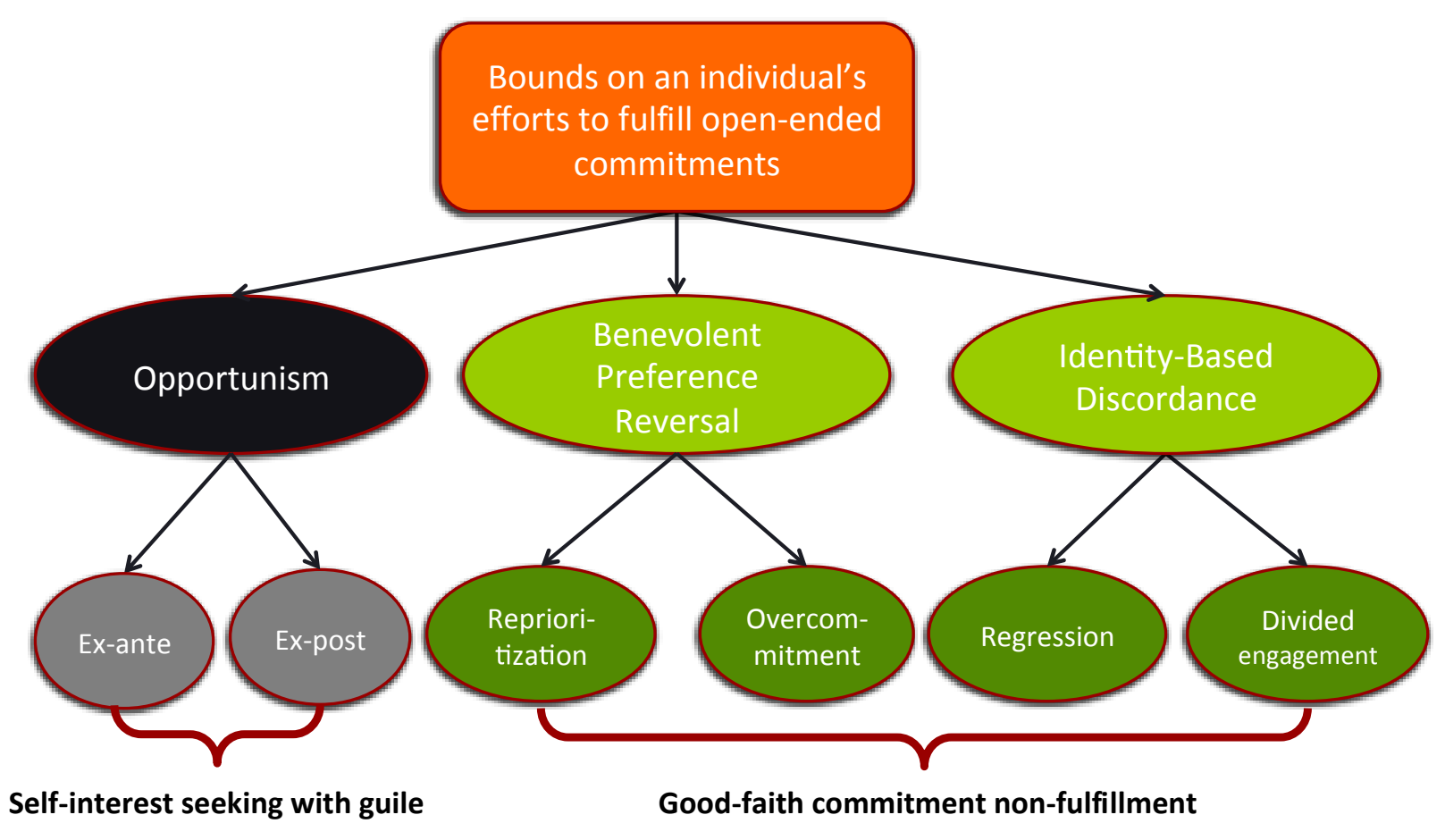


Table I. Safeguarding against the six dimensions of bounded reliability (BRel)

\begin{tabular}{|c|c|c|c|}
\hline \multicolumn{2}{|l|}{ BRel categories } & \multirow{2}{*}{$\begin{array}{l}\text { Safeguarding mechanisms } \\
\text { - } \quad \text { Contractual safeguards } \\
\text { - } \quad \text { Incentive alignment }\end{array}$} & \multirow[b]{2}{*}{$\begin{array}{l}\text { Specific examples of safeguards } \\
\text { - } \quad \text { Price hedging in supplier contracts } \\
\text { Building mutually beneficial clauses } \\
\text { into contracts with partners, e.g. } \\
\text { nominal payments between the Du } \\
\text { Pont and the Anglo-German group } \\
\text { of companies for the use of } \\
\text { European versus American } \\
\text { processes and methods in order to } \\
\text { keep parties satisfied with division } \\
\text { of world markets } \\
\text { Review of accounts for } \\
\text { irregularities; personal visits abroad } \\
\text { to monitor supplier/partner contracts }\end{array}$} \\
\hline Opportunism & Ex-ante & & \\
\hline & Ex-post & $\begin{array}{l}\text { - Legal action } \\
\text { - Discontinuation of } \\
\text { relationship }\end{array}$ & $\begin{array}{l}\text { - Mitigating effects of opportunism by } \\
\text { outside parties through courts } \\
\text { - Termination clauses in contracts; } \\
\text { employee dismissal }\end{array}$ \\
\hline \multirow{2}{*}{$\begin{array}{l}\text { Benevolent } \\
\text { preference } \\
\text { reversal }\end{array}$} & $\begin{array}{l}\text { Reprioriti- } \\
\text { zation }\end{array}$ & $\begin{array}{l}\text { - Organizational routines } \\
\text { to reduce cognitive } \\
\text { distance } \\
\text { - } \begin{array}{l}\text { Reduction of potential } \\
\text { friction among multiple } \\
\text { realities }\end{array} \\
\end{array}$ & 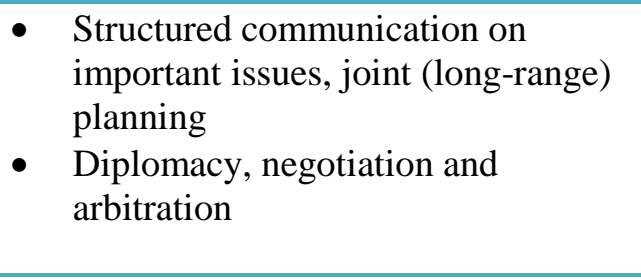 \\
\hline & $\begin{array}{l}\text { Over- } \\
\text { commitment }\end{array}$ & $\begin{array}{l}\text { - Organizational routines } \\
\text { to reduce impulsivity and } \\
\text { self-assessment bias }\end{array}$ & $\begin{array}{l}\text { Imposing limits on new activities; } \\
\text { realistic goal setting; utilizing } \\
\text { specialized expertise in goal setting; } \\
\text { joint goal setting; structured } \\
\text { governance practices }\end{array}$ \\
\hline $\begin{array}{l}\text { Identity-based } \\
\text { discordance }\end{array}$ & Regression & $\begin{array}{l}\text { - Organizational routines } \\
\text { to help unlearn old } \\
\text { practices } \\
\text { - Impression management } \\
\text { - } \begin{array}{l}\text { Discontinuation of } \\
\text { relationship }\end{array}\end{array}$ & $\begin{array}{l}\text { - Leadership to explain superiority of } \\
\text { new routines, training to adopt new } \\
\text { routines } \\
\text { - Communication/information sharing } \\
\text { - "Change of men" (dismissal) }\end{array}$ \\
\hline
\end{tabular}




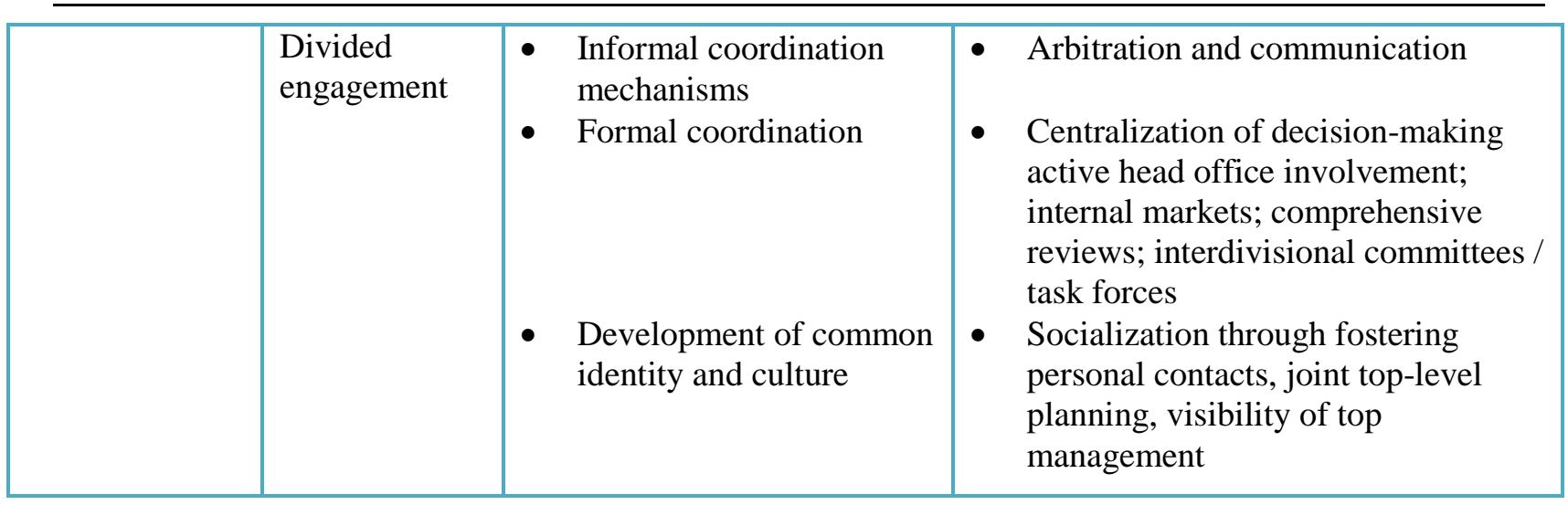

